\title{
INEVITABLE WAR, US DECLINE OR BUSINESS AS USUAL? NARRATIVES ON CHINA'S ASCENSION TO POWER AMONG AMERICAN ACADEMIA ${ }^{1}$
}

The last four decades have witnessed a remarkable growth of China's economic and military power accompanied by a relative decline of the material and normative status of the West. The changes in the distribution of power in the system have been accompanied by growing ambitions and aspirations of the Chinese leaders and concerns of their western counterparts. Since Xi Jinping's ascension to power in 2012, the Communist Party of China (CPC) has mostly abandoned the 'low-profile' policy introduced by Deng Xiaoping and replaced it by pursuit of more confrontational and assertive 'Great Power Diplomacy with Chinese Characteristics'. The ongoing modernization of the People's Liberation Army (PLA), and intensified political and economic engagement in such regions as the Middle East, Africa, Latin America, and Europe have attracted a lot of attention of the American academia, think-tanks, and politicians. 'The China question' gained even more momentum in the aftermath of the 2016 presidential campaign, Donald Trump's election and the trade war that followed.

While literature concerning China's rise is extensive and growing, the academic discourse itself has not attracted symmetrical attention. There are some notable examples of works oriented at analysing the American discourse about China. Aaron Friedberg capably reviewed the ongoing debate regarding the most suitable strategy to accommodate rising China and preserve American interests. Friedberg distinguished six strategic approaches to China, personally advocating intensified balancing combined with continued engagement as the most optimal way (Friedberg, 2015: 107). While this paper also deals with questions regarding the 'China debate', 'discourse' and 'narratives', the research problemsare distinct in comparison to the aforementioned papers, thus providing different insights. Since the accommodation of China's rise is perhaps one of the greatest challenges for the American foreign policy in the 21 st century, the construction of threat perception constructed through different narratives will play a pivotal role in whether the resolution will be peaceful or belligerent.

This article aims to identify and analyse the narratives on China's rise prevailing among the American academia. This focus is justified for three reasons: 1) In the US, China is one of the most discussed topics across political science resulting in a signifi-

${ }^{1}$ The research leading to these results has received funding from the project titled "Poland in the contemporary geopolitical and geostrategic conceptions" funded by the Ministry of National Defense of Poland and included in the War Studies Academy financial plan for $2017 \mathrm{nr} 306$ (project code III 1.7.0). 
cantly bigger number of publications compared to other nations; 2) When facing a vast number of works devoted to China it is impossible to refer to all of them, so one has to confine oneself to most influential and insightful authors, among which many are Americans. In this regard, David Shambaugh went as far as to conclude that 'the US academic community's expertise on China is unparalleled in the world' (Shambaugh, 2005: 17). US scholars are deeply engaged in the debate on China and, due to their functionalist approach to studying international relations, they exert influence on the decisions of authorities and public discourse of the world's only superpower.

This article explores the arguments, assessments, and predictions of selected scholars regarding China's current power and position in international relations as well as their projections of development of the US-China relations. The 'narrative' is understood as a written or spoken representation of a phenomenon or a process that promotes a specific point of view, set of values or aims. The analysis is oriented towards finding answers to three core questions, which in turn determine their further inclusion to a given narrative. The starting question: 'What is the current balance of power between the US and China?' is an essential one, yet not decisive, as the authors' estimations of the balance of power might be similar, but their interpretation strikingly different. The second question: 'Which of the variables has the greatest impact on the trajectory of Sino-American relations?' is probably the most important one since prioritization of a particular variable to a large degree determines final explanations and predictions. Finally, the third question: 'What are the perspectives of China's rise?' touch upon a very risky and error-prone area of forecasting in international relations. While a large share of analysed works take a cautious approach, given the spectacular failures of previous generations in this field (Lebow, 1994; Gaddis, 1993), it is still possible to distinguish the authors' inclinations towards one or other scenarios. Answers to these questions serve as criteria for later classification to three groups.

The author identifies three core narratives on 'China rise': pessimistic, balanced, and optimistic, which comprise most of the stances while taking into account their respective differences. The first narrative is primarily based on historical, geopolitical or structural analysis and predicts that China's rise to power will either inevitably spark a conflict between the US and China orthe risk of aconflict is greaterthan that of a peaceful resolution. The authors included in this narrative widely acknowledge China's relative gains and America's relative decline, but they are not necessary declinist in the sense that they expect the fall of US hegemony. This narrative is exemplified by the works of John J. Mearsheimer, Graham Allison, and Robert Ross. The second 'balanced' narrative features Thomas J. Christensen, Joseph Nye and Robert Art. The respective authors differ when it comes to the most significant determinants of the US-China relations however, an intellectual core that unites them is the assumption thata conflict with China is avoidable, yet not totally improbable. According to this narrative, China's rising power is a process that leads to the decline of American supremacy in the Asia-Pacific, yet its scope and depth should not be overestimated as the US holds a decisive advantage in most of the fields. The third narrative, classified as 'optimistic', refers to the works of scholars claiming that, despite its remarkable achievements, China has no potential to become a truly global power and replace the US as the world leader. The authors representing this strand of thought employ various 
arguments based on cultural, social, political and economic foundations. Their common link is the assumption that due to internal and external limitations, China does not pose a considerablethreat to the US position or the world order. Among these, the most prominent figures include John Ikenberry, William Wolforth, and Stephen Brooks.

\section{THE PESSIMISTIC NARRATIVE}

Declinism has been a recurring feature in American political and strategic thought, which manifested itself whenever the US was confronted with a great challenge such as the Great Depression (Kindleberger, 1986), WWII, Cold War or Japan's rise in the 1960s and 1970s. Paul Kennedy's The Rise and Fall of Great Empires, first published in 1989 (Kennedy, 1989) is probably the best-known book reflecting this 'declinist' perspective. Contemporarily, China's remarkable re-emergence onto the world stage has provided another stimulus to this long-lasting academic debate resulting in a number of insightful works. Some of them emphasize the perceived decline of American hegemony (Acharya, 2014; Zakaria, 2008; Kupchan, 2012; Walt, 2018), others go against these trends and criticize the 'declinist' approach (Joffe, 2014; Glaser, 2018; Wohlforth, 2016). While the assumption of the erosion ofthe US power constitutes a significant element of the pessimist narrative it is not the only one. Some authors, even though accepting the assumption of America's decline, argue in favour of a more optimistic future for the world and the United States. What exacerbates pessimism of the pessimists is not only the assessment of the deteriorating power of the West but rather the prospect of 'the rise of the rest' and China specifically. In the pessimistic narrative, these processes not only lead to transformation of the power structure of the system but are likely to generate conflicts. Especially in the 1990s and early 2000s the pessimistic narrative used to be confined to a narrow circle of conservative journalists (Broomfield, 2003: 266), military staff and individual scholars associated with offensive and 'rise and fall' realisms. Since the beginning of the 21st century, the American elites confronted with the dynamic rise of China started to shift their perspective toward a more critical approach which gave pessimistic narrative a strong momentum enhanced by the alarmist and widely popular books of Michael Pillsbury (2015), Martin Jacques (2009) or Peter Navarro (2008; 2015). Since the election of Donald Trump, the pessimist perspective has become a prevalent one in the administration which was reflected in a number of strategic documents such as National Security Strategy (The White House, 2017) and Indo-Pacific Strategy (Department of Defense, 2019) where China was referred to as a 'revisionist power'. This paper, however, focuses on the works of Graham Allison, Robert S. Ross, and John J. Mearsheimer which offer a more academic perspective on China's rise, and have become important reference points in the ongoing discourse.

Graham Allison begins his book with an insightful overview of China's advances in the economic dimension by showing that during one generation China surpassed the US in terms of currency reserves, GDP measured as PPP, and export volume. The Harvard Scholar further points to such institutions as the Asian Infrastructural Investment Bank, BRICS, Belt, and Road Initiative which are undermining the US-led insti- 
tutional regime (Allison, 2017: 3-24). This overview argues that one has to confront the dynamics of an aspiring great power - China and the descending hegemon - the US. What is the implication of this evolving power structure in the system? Graham Allison draws a rather disturbing picture demonstrating that since the Peloponnesian War power transitions produced profound structural stresses which in twelve out of sixteen cases led to great conflicts. In his analysis of American ascension and the British peaceful demise in the 19th and 20th centuries, Allison demonstrates that while this process did not lead to a great power conflict, it was far from being peaceful. The author highlights that during the decades since the arrival of Theodore Roosevelt the US 'declared war on Spain, expelling it from Western Hemisphere and acquiring Puerto Rico, Guam, and the Philippines; threatened Germany and Britain with war unless they agreed to settle disputes on American terms; supported an insurrection in Colombia to create a new country, Panama, in order to build a canal' (Allison, 2017: 90). Basing on these historical analogies to the American expansion, Allison asserts that events may take a similar course of as regards China's line of action toward the South China Sea and Taiwan (Allison, 207: 106). Therefore, even if Washington and Beijing manage to avoid a major military confrontation similar to the US-Japan war in the Pacific, there is still a distinct possibility of a limited regional conflict driven by China's pursuit of strategic depth.

To explain the genesis of conflicts between the ascending and descending hegemon Allison introduces the concept of 'Thucydides Trap' deriving its name from the ancient Greek historian who famously stated that: 'It was the rise of Athens and the fear that this inspired in Sparta, that made war inevitable'. According to Allison, there are two constitutive elements of the 'Trap': 1) Objective rise of a new power accompanied by the sense of revisionist entitlement; 2) Fear, insecurity, and determination to defend the status quo this engenders in the established power (Allison, 2017: xiv-xvi). What is driving the potential conflict is therefore the complex interplay of objective and subjective factors. Allison is far from stating that war is inevitable, in fact, the whole purpose of his book is to convince the audience to make a sustained effort in order to avoid war (Allison, 2017: viii-x). Nevertheless, Allison acknowledges that the ever-present danger of miscalculations on both sides may eventually lead to undesirable escalation. A confrontation of Allison's work with three above mentioned questions led the author to the following conclusions: 1) Allison recognizes the decline of the US and the ascent of China as this process is a precondition of 'Thucydides Trap' to emerge; 2) For Allison structural stresses imposed by the rise of new great powers constitute the most important force driving US-China relations; 3) The work rejects determinism, yet it leans toward pessimistic vision of China's rise.

As the founding father of 'offensive realism' and one of the most polarizing figures in IR theory John J. Mearsheimer offers a cohesive and incisive yet often criticized perspective on China's rise (even among realists) (Kirschner, 2010; Glaser, 2011). Mearsheimer argues that, due to the ontological nature of states and the international system, the Sino-American antagonism will be very difficult to avoid in the future. Since the primary motive of every state is to maximize its power at the expense of other actors, 'there are no status quo powers in the international system' (Mearsheimer, 2014: 2). Great powers possess greater ambitions that drive them to pursue the ultimate 
aim - hegemony - and China is not an exception. Mearsheimer compares the rise to power of the US and China concluding that China is very likely to follow this path and attempt to dominate its near-neighbourhood the same way the US dominated Western Hemisphere since the $19^{\text {th }}$ century and onward (Mearsheimer, 2014: 368-371). China's regional expansion would trigger the balance of power dynamics with the US and other regional powers such as Japan, India, South Korea, Singapore, Vietnam, and Russia determined to contain China's rise. These processes, in turn, would initiate a very intense security competition, which may result in a war. The picture painted by Mearsheimer is very bleak, indeed; however, much of criticism concerning his works do not take into account the conditionality of that vision. The author precisely indicates that his predictions only apply to the situation when China sustains a high rate of economic growth which will result in a significant change in the balance of power (Mearsheimer, 2014: 360-361). When it comes to the present American advantage, China "is in no position to challenge it in any meaningful way' (Mearsheimer, 2014: 360 ) and that 'China is still far from the point where it has the military capability to make a run at regional hegemony' (Mearsheimer, 2014: 384). It is worth noting that this assessment was made in the updated version of his work The Tragedy of Great Power Politics from 2014, which takes into account China's relatively recent advances.

By applying the three basic questions to Mearsheimer's theory the author concludes that: 1) The balance of power is still in strong favour of the US; 2) The most important element in future China-US relations will be an ontological and inherent drive of every state to achieve hegemony; 3 ) The Sino-American relations are doomed to be conflictual in the future under the condition that China's economy will grow at brisk clip and China will pose a real challenge to the US.

A similar vision is depicted by Robert $\mathrm{S}$. Ross, one of the leading experts observing China's re-emergence during the last decades. According to Ross, the current balance of power is undergoing a critical transformation driven by the rise of China and the ascension of other powers. With respect to China's current position, Ross finds that unless balanced by the US it has the potential to achieve regional hegemony (Ross, 2013: 20). Ross dismisses the case for offshore balancing as none of the American allies possess the power to successfully balance China and, in the light of its rise, it is not certain that they will align with the US interests (Ross, 2013: 24). Ross, similarly to Mearsheimer and Allison, concentrates on historical patterns of great-power politics and the stresses that it imposes on agents. For Ross, current motivations are not necessarily relevant, as he assumes that 'once China possesses the capabilities to challenge the regional order, it will presumably seek a dominant strategic position throughout East Asia.' (Ross, 2013: 24). The realization of this scenario depends upon the US' willingness and ability to balance China's rise and ensure that the cornerstone of US security remains unchallenged. Ross seems to attach the greatest importance to the material aspect of power with a particular focus given to military power. Analysing China's rise Ross emphasizes its growing A2/AD capabilities geared towards limiting America's military potential in the region.

The analysis of Ross' work leads to the conclusion that 1) The distribution of capabilities in the system is profoundly changing, enhancing the position of emerging powers and undermining the US standing in the international system, particularly in the 
Asia-Pacific region. Ross downplays the case for offshore balancing as the US stands as the sole actor capable of accommodating China's rise; 2) Ross, symptomatically of neorealism, focuses on the material aspect of power dismissing the real impact of normative factors such as state identity and official narrative of the Chinese authorities. 3) The American determination to maintain its military and economic position in Asia will be of pivotal importance for the future of Sino-American relations and the future of the continent.

The analysed works, despite their differences, tend to focus on the implications of structural shifts among great powers in the international system. Mearsheimer, Allison and Ross identify that changes in the distribution of power may generate stresses leading to a great power conflict. To a varying degree they dismiss the significance on non-material factors, assuming that once China's achieves the status comparable to the US, it will attempt to dominate Asia. The authors do not aim to address the question of China's ability to sustain its remarkable development but settle on the assessment that, if it does, that power transition between China and the US is likely to turn into a conflict.

\section{THE OPTIMISTIC NARRATIVE}

The optimistic narrative embraces a broad group of authors with various lines of argumentation and theoretical affiliations. What constitutes the intellectual core of the optimistic narrative is the shared belief that in the future China will not pose a direct threat to the US and peaceful accommodation of China's re-emergence is much more likely than armed confrontation. Some scholars reach this conclusion by emphasizing internal barriers to China's development (Shambaugh, 2013; Fenby, 2014). They point to enormous economic, demographic challenges and the political apparatus which iseither not willing to act or inept to resolve mounting difficulties effectively. They conclude that China is not capable of becoming a true hegemon as in the coming decades the Chinese authorities will be engrossed in efforts to alleviate domestic concerns. Others point out the fact that profound economic interdependence between China, the US, and other leading economies makes an all-out conflict a highly unlikely possibility. This line of argumentation was described by Helge Hveem and T. J. Pempel as 'The Kantian Peace Thesis' (Hveem, Pempel, 2016: 196-232). Some of the liberals highlight the inclusive character of the present world order, which enabled China to achieve its current status. According to this argument, as a beneficiary of the liberal international order China does not have any interest in overthrowing it (Ikenberry, 2008). In the optimistic narrative, since the Nixon era US-China rapprochement has always played an influential role in the American strategic discourse. American policymakers, as well as members of the academia, asserted that through liberalization of the Chinese economy and greater engagement in international institutions China would eventually evolve more toward a 'western-style' political system and economy (The White House, 1990: 12; Martel, 2015: 306; Friedberg, 2015: 90). This dynamics, according to the 'democratic peace thesis' would eventually produce a stable and peaceful security environment. This belief was strongly manifested in National Security Strategies from 
the early nineties when the US enjoyed the so-called 'unipolar moment'. Contrary to expectations, China's re-emergence was not accompanied by political liberalization; in fact, Xi Jinping's ascension to power in 2012 and 2013 accelerated the processes of power centralization and crackdown on human rights activists. What is more, the dynamic development of the offensive and A2-AD potential put into question the 'peaceful' character of China's rise. Presently, optimistic liberals have mostly abandoned hopes of China's democratization, since as Erich Weede concludes 'economic cooperation and interdependence provide much more hope for the immediate future than democratization' (Weede, 2010: 209).

John J. Ikenberry is probably the best-known author associated with the liberal and institutional perception of China's rise in the 21st century. His essay written for Foreign Affairs has met with both strong applause and criticism, making his argument one of the most recognizable in the ongoing discussion. Ikenberry's assessment of the current balance of power does not distinguish itself much from most of the authors since, in his opinion, ascending China and the eroding power of the West is a historical fact. Ikenberry makes a clear statement that "The United States "unipolar moment" will inevitably end' and that 'If the defining struggle of the twenty-first century is between China and the United States, China will have the advantage' (Ikenberry, 2008: 25). However, contrary to some pessimists, Ikenberry argues that China's rise and a possible power transition is not likely to emulate violent cases from the past, as the current situation does not have a precedent in history. Ikenberry puts in the centre of analysis the western world order which 'is hard to overturn and easy to join' and has to be considered as the most relevant factor influencing China's rise (Ikenberry, 2008: 24). Ikenberry remains optimistic in regard to the Western international system and the West which are likely to score a 'triumph' over rising China. Ikenberry advocates closer engagement with China aiming to strengthen the current international rules and institutions, which can help the system outlive the decline of the West (this strategy has been described by Aaron Friedberg as 'enhanced engagement' Friedberg, 2015). For Ikenberry, the Western liberal order is a unique phenomenon that delivered enormous economic growth and enabled the US to integrate its potential and that of its ex-rivals such as Germany, Japan, Russia, and China with the world economy. China, according to Ikenberry, is in fact one of the greatest beneficiaries of this system, and given that does not have any strong incentives to overturn it. What is more, the existence of nuclear weapons in American and Chinese arsenals creates unprecedented offensive capabilities that restrain respective decision-makers. Ikenberry consequently argues that 'The Western order has the potential to turn the coming power shift into a peaceful change on terms favourable to the United States' (Ikenberry, 2008: 33).

Summing up, Ikenberry: 1) Considers the end of the American 'unipolar moment' as a reality and presumes that in the long term China will gain the advantage over the US in terms of material assets; 2) For Ikenberry, the robustness of the Western international liberal order will be crucial to accommodate China peacefully. Enhanced engagement of the US and its allies with the developing countries and the strengthening of the rules and multilateral mechanisms can alleviate tensions resulting from power transition dynamics; 3) Ikenberry remains optimistic as regards the future of China's rise as long as the West continues its striving to bolster and reinvigorate the current system. 
William Wohlforth and Stephen Brooks, in opposition to the declinist positions asserting gradual erosion of US international power, argue that US dominance has only slightly if at all weakened since the 1990s. In their view, the power gap between the US and China is so considerable that no major change will take place until at least mid-century (Wohlforth, Brooks, 2016: 8). This assertion is based on the analysis of three core elements of material power: 1) military capacity, 2) economic capacity, and 3 ) technological capacity supported by a broader historical reflection on the changing nature of power. According to the authors these three elements are closely interrelated and help better depict real state power. Wohlforth and Brooks criticize the approaches overestimating the importance of China's rising military expenditure by demonstrating that contemporarily the process of building military power demands decades of development (Wohlforth, Brooks, 2016: 18-19). The current US technological and organizational military superiority results from the accumulation of resources and experiences over an extended period. To close the gap separating it from the US China will have to maintain high expenditure over many decades and that process might be impeded by the US internal balancing efforts and China's internal challenges. To illustrate the real balance of power between China and the US Wohlforth and Brooks use the conceptual framework of Barry Posen's emphasizing "the command of the global commons." The authors argue that the command of the commons (sea, space, air) is a 'key enabler' of US global power and since the Gulf War the American advantage over other actors is unprecedented (Wohlforth, Brooks, 2016: 22). Similar conclusions are drawn in the analysis of the technological and economic dimensions of power. The authors underline that in today's globalized economy GDP is not a sufficient analytical tool to track state economic power. While GDP estimations suggest that the US power is declining, others show that it is not undergoing any dramatic changes. The authors also try to prove that American technological dominance is still far from being seriously contested as the United States remains the primary source of innovations. The authors identify three core structural barriers that will be pivotal to China's evolution from potential to actual superpower. Firstly, China's technological gap vis-à-vis the US is significantly bigger than those of previous rising states, such as the Third Reich or Japan, which makes transition proportionately more difficult. Secondly, due to the growing technological sophistication of top military equipment, the complexity of its development and operationalization is much higher. Thirdly, Chinas future ascent to the superpower status has to overcome the unprecedented US military superiority. (Wohlforth, Brooks, 2016: 40-41). In light of the above, no power in the world has the capability to balance the United States and that situation is likely to remain unchanged for decades to come. Even China's rise to the emerging potential superpower level does not considerably alter this reality. Wolhforth and Brooks do not explicitly take a stance regarding future China-US relations. However, the assessment of the distribution of capabilities in the system they offer implies that China will not try to openly confront US powersoon. Given the existing disequilibrium of military power, it would result in a decisive defeat for China and the end of its 'Great Rejuvenation of the Chinese Nation'.

The author concludes that Wohlforth and Brooks: 1) Contrary to many scholars and pundits highlight the unprecedented and lasting US advantage over other powers in 
the system;China's re-emergence, while it constitutes an important dynamic, does not substantially change this reality; 2) The argument almost exclusively focuses on the material aspects of power, namely the military, technological and economic ones. The authors debunk the assumptions of China levelling with the US by demonstrating that in these key areas it still significantly lags behind. The authors do not explicitly address the question of future US-China relations; nevertheless, their argument on American primacy indicates that China does not possess sufficient instruments to confront the United States successfully. Therefore, the danger of a future all-out conflict remains moderate.

\section{THE BALANCED NARRATIVE}

The balanced narrative formsa bridge between the pessimistic and optimistic narratives by taking into account both risks and opportunitiesengendered by the rise of China. What links it with the pessimist narrative is a vigilant approach toward the rising military potential of the Chinese state driven by nationalistic and authoritarian domestic policies. It recognizes relative deterioration of the US position, but at the same time it is far from overestimating China's advances. In this narrative, the balance of power is still visibly in favour of the US primarily due to its military potential and unrivalled system of alliances in the Asia Pacific (Christensen, 2015; Friedberg, 2011; Nye, 2015; Shambaugh, 2013). With the optimistic narrative, it shares the attention that is given to the conditions constraining China's future risk such as the lack of proven allies, economic and social challenges as well as the premodern political system. It assumes that a prospective Sino-American conflictis not as improbable as many optimists may suggest, but less likely than the pessimist narrative would have it. Many contemporary scholars linked with structural and realistic perspectives, such as Joseph Nye, Charles Glaser, Thomas Christensen, fall into the category of the balanced narrative.

Thomas J. Christensen's contribution to the ongoing discourse comes in the form of awidely acclaimed and discussed book: The China Challenge: shaping the choices of a rising power. Christensen's narration on China fits perfectly in the balanced narrative as the author situates himself between pessimists and optimists (Christensen, 2015: 2). Together with some optimists Christensen shares the scepticism as regards China's ability to become a peer competitor for the United States (Christensen, 2015: 95). The author emphasizes the enduring primacy of the US military (Christensen, 2015: 64) and the unrivalled system of alliances it enjoys in East Asia (Christensen, 2015: 51). Yet Christensen also acknowledges the process of America's relative decline which has escalated quickly in the 21 st century as a consequence of unreasonable fiscal policies and global dispersal of US forces (Christensen, 2015: 2). However, Christensen makes an important observation that 'security challenges do not come from peer competitors alone' (Christensen, 2015: 2), which brings him closer to the stance of David Shambaugh, who similarly argued that the relative US advantage over China does not necessarily translate into peaceful relations in the future. Christensen, similarly to Christopher Cooker, argues that the historical dynamics that led to great power conflicts in the past, which was highlighted in Allison's work, are contemporarily not as prominent 
as they used to bein Asia or Western Hemisphere (Christensen, 2015: 38-42, 62). The author refers to the arguments employed by the optimists regarding the unparalleled level of interdependence between China and the rest of the world (Christensen, 2015: 42) and the inclusive character of the international institution system established by the US and its allies after WWII, which enabled and facilitated China's re-emergence. For Christensen, the existence of nuclear weapons, economic interdependence and accumulated military power of the US and its allies provide strong incentives for the Chinese leaders to avoid conflict.

As shown above, in his book Christensen takes into consideration a broad range of arguments put forth both by the pessimists and the optimists. As a neoclassical realist Christensen tries to include a structural perspective inherent to neorealism and neoliberalism as well as the determinants existing at the state level. To Christensen, the military supremacy of the US supported by bilateral agreements with the Asian power along with economic interdependence constitutes the defining elements of the future of Sino-American relations. As regards the future, Christensen recognizes that rising China will pose a challenge to the US global interests and regional stability (Christensen, 2015: 63); nevertheless, the great power conflict is rather unlikely as most of the incentives favour peace rather than war.

By applying the three above mentioned questions to Christensen's work, the author concludes that: 1) The balance of power is still in strong favour of the US; 2) The most important element in future China-US relations will be an enduring American military primacy coupled with economic interdependence; 3) The Sino-American relations are not likely to escalate into a great power conflict, as most of the incentives push against it; however, China will pose an increasingly difficult challenge to US policy makers.

Joseph Nye, who t advanced the concept of 'complex interdependence', 'soft power' and 'smart power', provides another insightful perspective that can be identified as 'balanced'. Nye published two short, essay-like books referring to China's reemergence in the international system: first: The future of power (2011) and second Is the American century over? (2015), which will serve as the object of analysis. In the aforementioned works, Nye acknowledges the relative growth of China's power at the expense of the United States, yet he is far from assuming that China will become the next dominant power in international relations. Nye distinguishes three ways of using power to 'get the outcomes one wants': 1) coercion, 2) payment, 3) attraction or persuasion (Nye, 2015: 3-4). To verify the current balance of power, Nye compares China and the US in terms of their influence on the international system, sophistication of the economy, the strength of the financial sector, technological advancement, number and quality of alliances. These reflections lead him to the conclusion that: 'China still lags far behind the United States in all three dimensions of power, and has focused its policies primarily on its region and on its economic development' (Nye, 2015: 47). Nye estimates that the disparity in power between China and the US, while decreasing in favour of the former, is likely to endure for a long period as China faces numerous obstacles to its development (Nye, 2015: 49).

Nye takes into account a broad range of factors, but he attaches utmost importance to the US alliance complex in the Asia-Pacific region and the potential balancing actions by leading Asian powers such as India and Japan or Australia. Nye asserts that 
'the rise of Chinese power in Asia is contested by both India and Japan (as well as other states) and that provides a major power advantage to the United States' (Nye, 2011: 186). He also observes that the Chinese efforts to expel the United States from the region are most likely doomed to fail as American presence is desired by other regional powers which can either engage China to take a more responsible role or hedge against its revisionist actions. This assertion remains congruent with the realist balance of power theory, especially with its refined version - Stephen Walt's balance of threat theory (Walt, 1985: 8-15).

When it comes to the future, Nye is more preoccupied with the rise of 'others' than with the 'rise of China' (Nye, 2015: 23). He cautiously predicts that America will retain its central place in the world order at least until 2041, and China will not equal American power projections any soon. Due to the diffusion of power among many states such as China, India, Brazil, Russia, the pre-eminence of the United States will erode (Nye, 2015: 97); however, no country is likely to become powerful enough to surpass the US. While Nye does not perceive China as the next global superpower, he anticipates that its rising military capabilities will become increasingly challenging to the US primacy in China's near seas (Nye, 2015: 58). Nye does not unambiguously dismiss the prospect of Sino-American conflict, however, he deems it as a distant possibility: "miscalculations are always possible, but conflict is far from inevitable" (Nye, 2015: 69).

Nye's work provides the following answers to the adopted methodological questions: 1) China has made a remarkable progress, but the United States' advantage, despite growing challenges, persists in three most important dimensions of power (coercion, payment, attraction); 2) Among many factors, Nye asserts that it is the American system of alliances in the Asia-Pacific and the presence of vigilant regional powers (India, Japan) that is likely to curtail China's expansion and preserve the US positon; 3) The future of US-China relations is likely to be marked by increasing tensions, but most of factors act against the full-blown conflict scenario.

Robert J. Art offers another insightful perspective that can be ascribed to the balanced narrative. The analysis starts with a general overview of the changing balance of power. Art asserts that in absolute terms the US is still the most powerful country in the world, its material power is on the rise and the military has an advantage that is not likely to be challenge in the foreseeable future. However, in terms of relative power, Art observes that power in the system is diffusing. For Art, the rise of China is 'inexorable' and the United States is not capable of containing it economically as it would be almost equally disruptive to its economy and would depend on the compliance of other states (Art, 2010: 363-365). Accroding to Art, the "compound containment" was hardly manageable during the Cold War, even though the US and the Soviet Union were largely independent in terms of economy.

For Art, the future of China's rise depends primarily on decisions of Chinese leaders and as long as they make the right choices China's remarkable re-emergence will continue, therefore "China's rise is China's to lose" (Art, 2010: 366). Art considers the pessimistic vision of the future to be highly unlikely as the three key variables provide strong incentives for peaceful resolution (Art, 2010: 372). Art analyses three cases of great power competition from the last century through the prism of three variables: the 
level of security enjoyed (or believed to be enjoyed) by both parties vis-à-vis each other, economic interdependence, and ideological competition (Art, 2010: 366-367). The author does not claim to offer a universal theory of war and peace, but underlines that the above mentioned factors are the most significant ones to determine the intensity of hostilities and probability of a conflict. Out of three, it is the level of security (real or perceived) that constitutes the most powerful force shaping relations, among the established and aspiring hegemon. Art emphasizes that economic interdependence under the right conditions, reduces the risk of military conflict but by no means it is decisive. For example between 1914 the level of economic interdependence between the Great Britain and Germany was significant, and the level of ideological competition low, but it did not prevent war as the level of insecurity remained high. The same conclusions are drawn in regard to ideological completion, on the one hand, the larger axiological differences between the states, the higher are chances of arms races, security dilemmas and war. On the other, Cold War provides an example of intense ideological competition which was relatively peaceful.

Art, despite drawing insights from historical hegemonic transitions, asserts that Sino-American competition consist of distinct elements and the right set of policies can at least partially diffuse the conflict (Art, 2010: 360). The author predicts that if China's power grows, so will their ambitions, since "expanding power creates new goals" (Art, 2010: 361). Growing nationalism on the Chinese side and more assertive policy will put a test on American credibility toward its allies, particularly Japan and South Korea. For Art the key to maintain required degree of security vis-à-vis each other is the maintenance of American maritime supremacy in East Asia and the offensive capabilities of its nuclear arsenal, the creation of multilateral security institutions in the region, and the enhancement of existing alliances. Art recognizes challenges arising from the new security challenges, but also underlines that these daunting problem are surmountable, which will demand great efforts both from the Chinese and American leaders.

Robert Art's work provides the following answers to the adopted methodological questions: 1) In the long-term perspective China's rise is more or less 'inexorable', but it does not mean that US position is close to be challenged; 2) The level of real or perceived security of the US and China is the most significant factor to look at in determining the possibility of conflict. Ideology and economic interdependence also play a role, but it is of lesser influence than the first variable; 3 ) The development of Sino-American hegemonic transition will be shaped by the ability of political leaders to maintain satisfactory level of security and credible instrument of deterrence and institutional mechanisms.

This paper attempts to structure the ongoing discourse on China's rise among the American academia by distinguishing three prevalent narratives: pessimistic, balanced, and optimistic. It has been shown that among scholars the pessimistic narrative tends to recognize that balance of power is changing to the disadvantage of the US. They also emphasize structural stresses imposed on agents by either the nature 
of the anarchical system, balance of power dynamics, or great power transitions. Pessimists find that these dynamics are likely to step up the security competition which eventually may produce a great power conflict between the US and China. Contrary to that point of view, optimists remain sceptical of both China's ability to surpass the US and become a truly global superpower and of the revisionist character of its rise. They do not constitute a coherent group since they stress various aspects such as the challenges of domestic reforms, the preponderance of the US power, the importance of economic interdependence, and the lack of an alternative vision of the world order. Therefore, they consider a great power conflict between China and the US a highly unlikely possibility. The balanced narrative takes the middle road trying to get the best of both worlds. Representatives of this narrative do not contest challenges posed by rising China to the US interests in the Asia-Pacific, yet they also accept many arguments advanced by optimists regarding complex economic interdependence, the endurance of international system created by the US and its allies or China's internal barriers. This narrative tends to focus on the importance of American military presence and superiority in the Asia-Pacific as the strongest argument against the US-China conflict. While this narrative highlights incentives for peaceful accommodation it does not discount the possibility of a conflict, as security challenges do not always arise from peer competitors.

It is impossible to grasp the entire spectrum of opinions on China in their diversity and entirety as any selection to a larger or lesser degree will be subjective and authoritative. While it is impossible to refer to all relevant and valuable voices, it is perfectly plausible to construct broader categories based on shared traits that can embrace a broader body of works. Even basic categorization which takes into consideration the most significant differences helps to interpret the ongoing debate in a more structured and critical way. Three presented narratives may not cover all the angles but provide a general framework encompassing a major share of works. Following the observation made by constructivists that a discourse both shapes and is being shaped by social actors, it becomes increasingly significant to analyse how particular narratives influence perception of threat by the US and China. It is not only constructivism that recognizes the importance of the discursive and perceptual element -the realist conception such as the 'security dilemma' (Glaser, 1997) or the 'balance of threat theory' (Walt, 1985: 8-15; 1990) consider them as pivotal to understanding peace and conflict dynamics. Therefore the shifting perception and changing popularity of a given narrative might be an indicator of a more profound strategic adjustments in the US strategy.

\section{REFERENCES}

Acharya A. (2014), The End of American World Order, Polity Press, Cambridge.

Allison G. (2017), Destined for war: can America and China escape Thucydides trap?, Scribe, London-Melbourne.

Art R. J. (2010), The United States and the Rise of China: Implications for the Long Haul, "The Journal of Public and International Affairs", Vol. 125, No. 3, pp. 359-391. 
Brooks S. G., Wohlforth W. C. (2016), The Rise and Fall of the Great Powers in the Twenty-first Century: China's Rise and the Fate of America's Global Position, "International Security", Vol. 40, No. 3, pp. 7-53.

Christensen T. J. (2015), The China challenge: shaping the choices of a rising power, Norton, New York.

Department of Defense (2019), Indo-Pacific Strategy Report: Preparedness, Partnerships, and Promoting a Networked Region.

Friedberg A. (2011), A contest for supremacy: China, America, and the struggle for mastery in Asia, W.W. Norton, New York-London.

Friedberg A. (2015), The Debate Over US China Strategy, "Survival”, Vol. 57, No. 3, pp. 89-110, DOI: 10.1080/00396338.2015.1046227.

Gaddis J. L. (1993), International Relations Theory and the End of the Cold War, "International Security", Vol. 17, No. 3, pp. 5-58.

Glaser C. (1997), The Security Dilemma Revisited, "World Politics", Vol. 50, No. 1, pp. 171-201.

Glaser C. (2011), Will China's Rise Lead to War? Why Realism Does Not Mean Pessimism, "Foreign Affairs", Vol. 90, No. 2, pp. 80-91.

Glaser J. (2018), Status, Prestige, Activism and the Illusion of American Decline, "The Washington Quarterly", Vol. 41, No. 1, pp. 173-197, DOI: 10.1080/0163660X.2018.1445903.

Ikenberry J. G. (2008), The Rise of China and the Future of the West. Can the liberal system survive?, "Foreign Affairs", Vol. 87, No. 1, pp. 23-37.

Kennedy P. (1989), The rise and fall of the great powers: economic change and military conflict from 1500 to 2000, Random House, New York.

Kindleberger C. (1986), The World in Depression 1929-1939, University of California Press, Berkeley.

Kupchan C. A. (2012), No one's world: the West, the rising rest, and the coming global turn, Oxford University Press, Oxford.

Lebow R. N. (1994), The Long Peace, the End of the Cold War, and the Failure of Realism, "International Organization", Vol. 48, No. 2, pp. 249-277.

Lyle J. Goldstein (2015), Meeting China halfway: how to defuse the emerging US-China rivalry, Georgetown University Press, Washington.

Martel W. C. (2015), Grand Strategy in Theory and Practice, Cambridge University Press, New York. Mearsheimer J. J. (2014), The Tragedy of Great Power Politics, W. W. Norton, New York-London.

Nye J. S. (2011), The future of power, Public Affairs, New York.

Nye J. S. (2015), Is the American Century Over?, Polity, Cambridge-Malden.

Shambaugh D. (2005), The new strategic triangle: U.S. and European reactions to China's rise, "The Washington Quarterly", Vol. 28 No. 3, pp. 5-25, DOI: 10.1162/0163660054026470.

Shambaugh D. L. (2013), China goes global: the partial power, Oxford University Press, Oxford.

Shambaugh D. L. (2016), China's future, Polity Press, Cambridge.

The White House (1990), National Security Strategy of the United States.

Vogel Ezra (1979), Japan as Number One: Lessons for America, Harper\&Row, New York.

Walt S. W. (1985), Alliance Formation and the Balance of World Power, "International Security", Vol. 9, No. 4 (Spring), pp. 3-43.

Walt S. W. (1990), The Origins of Alliances, Cornell University Press, Ithaca-London.

Weede E. (2010), The Capitalist Peace and the Rise of China: Establishing Global Harmony by Economic Interdependence, 36: 2, 206-213, DOI: 10.1080/0305062100378518.

Zakaria F. (2008), The post-American world, W. W. Norton \& Company, New York-London. 


\begin{abstract}
This article aims to analyse prevalent narratives on China's rise among American academia. The attribution of a scholar to a given narrative depends on how their ideas and arguments resonate with three pivotal questions: 1) what is the current balance of power between the US and China?; 2) which variables and determinants have the greatest impact on the trajectory of Sino-American relations?; 3) what are the prospects of China's rise?. The author identifies three core narratives: 1) pessimistic which acknowledges deteriorating position of the West and anticipation of a conflictual character of future relations between China and the US; 2) a balanced view that recognizes a relative decline of the US, but also assumes that China's re-emergence has apparent limitations. Potential hegemonic war is both probable and avoidable either through deeper engagement or different forms of balancing; 3) an optimistic narrative which stresses internal and external barriers to China's development that preclude its potential rise to global leadership or the preponderance of American power which is likely to endure in coming decades. The Author adopts constructivist approach and employs methods of critical discourse analysis and categorization.
\end{abstract}

Keywords: China, US, security, power, international perception, narrative

\title{
NIEUNIKNIONA WOJNA, UPADEK USA CZY BIZNES JAK ZWYKLE? NARRACJE O WZROŚCIE POTĘGI CHIN W AMERYKAŃSKIM DYSKURSIE AKADEMICKIM
}

\begin{abstract}
STRESZCZENIE
Niniejszy artykuł ma na celu analizę dominujących wśród amerykańskich kręgów naukowych narracji dotyczących wzrostu potęgi Chin. Przyporządkowania określonego badacza do danej narracji uzależnione jest od sposobu, w jaki prezentowane przez niego idee i argumenty odpowiadają na trzy kluczowe pytania: 1) Jaka jest obecna równowaga sił pomiędzy Stanami Zjednoczonymi i Chinami?; 2) Które czynniki i determinanty najsilniej oddziałują na kierunek rozwoju relacji Chiny-USA?; 3) Jakie są perspektywy wzrostu potęgi Chin? Autor identyfikuje trzy podstawowe narracje: 1) pesymistyczna, uznająca osłabienie pozycji Zachodu i przewidująca konfliktowy charakter przyszłych relacji chińsko-amerykańskich; 2) zrównoważona, która dostrzega relatywne osłabienie Stanów Zjednoczonych, ale zarazem uznaje, że wzrost potęgi Chin ma wyraźne ograniczenia. W tym ujęciu konflikt hegemoniczny jest prawdopodobny, ale można go uniknąć poprzez głębsze zaangażowanie lub różne formy równoważenia; 3 ) optymistyczna narracja podkreślająca wewnętrzne i zewnętrzne bariery dla dalszego rozwoju Chin, które uniemożliwiają im osiągnięcie światowego przywództwa, lub też trwałość amerykańskiej dominacji w nadchodzących dekadach. Autor przyjmuje podejście konstruktywistyczne i opiera się na metodach krytycznej analizy i kategoryzacji dyskursu.
\end{abstract}

Słowa kluczowe: Chiny, USA, potęga, bezpieczeństwo, percepcja międzynarodowa, narracja 
